\title{
PLANEJAMENTO URBANO E REPRESENTAÇÕES SOCIAIS NO BAIRRO CAPELA VELHA, ARAUCÁRIA/PR
}

\author{
Urban planning and social representations in the \\ neighborhood Capela Velha, Araucária/PR
}

\author{
Neide de MOURA ${ }^{1}$
}

Miguel $\mathrm{BAHL}^{2}$

\begin{abstract}
RESUMO
O presente trabalho tem como objetivo analisar as representações sociais oriundas das ações do Planejamento Urbano no bairro Capela Velha do Quadro Urbano do Município de Araucária/PR. Tais representações emergem em meio a um turbilhão de informações, percepções e relações sociais inerentes à prática social dos moradores do bairro, que em seu cotidiano subtraem informações dos mais variados meios, inclusive das ações de poder, e constroem com base nisso seu referencial imagético. Sendo assim, as representações tratadas neste trabalho de pesquisa se dão num espaço simbólico, ou seja, um espaço de relações (BOURDIEU, 2003), que para o trabalho desenvolvido, atuou como elo entre as representações sociais e a Geografia.
\end{abstract}

Palavras-chave: Araucária/PR: Bairro Capela Velha; Representações sociais; Espaço de relações; Planejamento urbano; Prática social.

\section{ABSTRACT}

This paper aims at analyzing the social representations from the City Planning actions in Capela Velha neighborhood in the urban square in Araucaria/PR. Such representations emerge among a flurry of information, perceptions and social relationships related to the neighborhood residents social practice. In their daily practice they subtract information from several places, including from the power actions, and they build on this their imagery reference. Therefore, the representations made in this research take a symbolic space; in other words, a space of relations (BOURDIEU, 2003) which, hereby, was used as a link between social representations and Geography.

Keywords: Araucaria/PR: Capela Velha neighborhood, Social representations, Space of relations, Urban planning, Social practice.

1 Mestre em Geografia - Universidade Federal do Paraná (UFPR). E-mail: neidedemoura@gmail.com

2 Professor do Programa de Pós-Graduação em Geografia e do Curso de Turismo (UFPR). Doutor em Ciências da Comunicação (USP).E-mail: migbahl@ufpr.br 
MOURA, N.; BAHL, M. Planejamento urbano e representações sociais...

\section{INTRODUÇÃO}

Uma cidade, como espaço urbano, guarda em si uma gama de elementos e interfaces que subtraem pensamentos operantes e inoperantes dentro do campo imagético dos indivíduos que a vivenciam. Está repleta de anseios, imagens, percepções e representações que transitam livremente pelos seus mais ínfimos meandros. Constituída de formas físicas impregnadas de formas simbólicas, fica sempre a espera de algo novo, que a transforme por inteiro ou apenas em alguma parte. A rotatividade presente em suas entranhas intriga e instiga ao mesmo tempo seus atores e contempladores, que divagam sobre suas conceituações, sobre seus contextos, procurando encontrar respostas às perguntas que elaboram a seu respeito. Neste sentido, seu estudo repercute entre as ciências originando os mais diversos tipos de pesquisas e análises.

Diversas são as maneiras pelas quais ela pode ser observada e encarada. Como objeto, como imagem ou como fenômeno. Como objeto, são aplicados conceitos, fórmulas, modelos na intenção de se chegar a generalizações expressas sob a forma de leis gerais, que podem servir a qualquer cidade, esteja ela onde estiver. Como imagem, é alvo de percepções particulares ou coletivas, podendo ser equivalente a um produto que pode ser vendido e consumido. E, por fim, como fenômeno, pode ser analisada em suas mais profundas particularidades, como sendo única e distinta entre todas as outras. Sem generalizações ou imagens produzidas, apenas como um fenômeno, o fenômeno urbano, para o qual se buscam não leis, mas sim análises não definitivas e que ao mesmo tempo mencionam muito sobre sua organização e sobre o modo como é vista pelos que dela fazem uso. É neste âmbito que aqui será tratada, como um fenômeno, do mesmo modo que as representações sociais são para Moscovici (2007), um fenômeno que merece ser analisado e não conceituado.

Neste sentido, a cidade foco das pesquisas deste trabalho tem tanto quanto outras tantas existentes, as mais distintas faces e fontes de análise. Selecionou-se a cidade de Araucária, situada na Região Metropolitana de Curitiba, Estado do Paraná.

Levando-se em conta a enorme gama de eventos que se apresentam nas cidades, optou-se por um em especial, pelo fato do mesmo se constituir em elemento novo dentro do campo da Geografia, ou seja, a abordagem utilizada propiciou uma interpretação diferente, pois foi levado em conta o intersubjetivo em seu processo de análise. Sendo assim, o presente artigo teve como objetivo geral a análise das representações sociais ge- radas pelas ações do Planejamento Urbano no bairro Capela Velha, Município de Araucária/PR.

\section{O AMBIENTE URBANO. AMBIENTE?}

O urbano traz, imbricado em seu conceito, inúmeras nuances: áreas urbanizadas, altas concentrações populacionais, desenvolvimento industrial acelerado, um estatuto. Além destes aspectos de ordem legal, também merecem atenção as particularidades culturais atuantes no seio da sociedade urbana, ao passo que estas podem ser analisadas sob diferentes dimensões que se interpenetram.

Sendo assim, pode-se dizer que o urbano se constitui no ambiente social e culturalmente modificado com o objetivo de servir de palco à morada humana, atendendo suas necessidades gerais. Então, uma cidade, as formas que a caracterizam sobre o espaço geográfico, podem ser chamadas de ambiente urbano. Uma cidade é um ambiente.

Entretanto, quando a expressão 'ambiente' é utilizada, na maioria das vezes, entra no sentido evocativo a noção de natureza 'natural'. Gonçalves (2002) argumenta que muitas vezes no cotidiano da sociedade a natureza é definida como aquilo que se opõe a cultura. Sem querer entrar no mérito das discussões do conceito de natureza, basta salientar a noção de natureza, substituída pelo termo 'ambiente' como um conceito adicionado à palavra 'meio', correspondendo juntos a um lugar específico, com características e seres específicos, que se contrapõe à ideia de cidade, que por sua vez, pode conter estes elementos em lugares predeterminados.

Para a especificidade acerca das discussões das representações do ambiente que se constituem no enredo desta pesquisa, o termo cidade será tratado como 'ambiente urbano', palco das ações e relações do homem. Sendo assim, é passível de receber valores qualitativos por parte daqueles que o habitam. $\mathrm{O}$ presente estudo de caso prevê a análise do planejamento urbano por meio das representações sociais do ambiente num cenário organizado pelas ações do poder público municipal, delimitado por usos diferenciados (residencial e industrial) que serão posteriormente especificados. Tais usos definem as características ou os valores qualitativos do ambiente urbano em estudo. Então, pode-se dizer que o ambiente urbano carrega em si um predicado ambiental. 
MOURA, N.; BAHL, M. Planejamento urbano e representações sociais....

\section{AMBIENTE REAL. REALIDADE AMBIENTAL}

Compreendendo o ambiente urbano como algo real, e a terminologia 'ambiental' como uma realidade, é que se pretende teorizar este subitem. Parte-se do princípio de que o espaço representa aquilo que existe, ou seja, uma realidade, e que as leis de Planejamento Urbano representam aquilo que deveria ser, ou seja, o que é real (ou poderia vir a ser). Sendo assim, o trabalho de análise dos dados buscou avaliar as interferências entre o real e a realidade, num jogo em que o primeiro é colocado como base para o segundo, mas que por sua vez, extrai deste os elementos de que necessita para a constituição de si enquanto materialidade.

Ao mesmo tempo em que extrai elementos para a formação daquilo que é real, a realidade também faz com que o real se adapte de alguma maneira às suas necessidades. Deste modo, o real e a realidade se interpenetram, dando origem às representações sociais, que por sua vez se inscrevem em um espaço próprio, formado durante o processo de interpenetração, ao qual aqui é chamado de espaço de relações, a ser discutido posteriormente. O processo de criação das representações no espaço de relações faz com que a realidade se fragmente e se transforme no produto do universo consensual. Moscovici (2007, p. 31) salienta que os homens têm a tendência natural de fragmentar a realidade. Diariamente classificam coisas, pessoas e situações de acordo com os interesses vigentes. Isto faz com que determinados objetos ou fatos fiquem visíveis ou invisíveis dependendo do contexto em que se inserem. Assim, também se podem compreender as relações cotidianas entre homem e meio: elas se mostram dotadas de valores que se manifestam ou que passam despercebidos, dependendo das necessidades e/ou funções por ele exercidas.

O homem sempre busca a compreensão daquilo que o cerca, ou seja, da realidade. Moscovici (2007) afirma que é este fato que o distingue do/no ambiente, já, segundo o mesmo autor, o que distingue o ambiente é o fato deste possuir completa autonomia e independência com relação ao homem, podendo-se mesmo dizer que possua "indiferença com respeito a nós e as nossas necessidades e desejos" (p. 30). Pensando-se assim, a realidade não se circunscreve necessariamente à vontade humana. Entretanto, a realidade do ambiente, ou seja, seu predicado ambiental é percebido pelos indivíduos cotidianamente, tornando-se parte de sua prática social. Assim, sujeita a realidade às suas ações, transformando-a rotineiramente. Para Moscovici (2007, p. 31) "distinguimos a aparência da realidade das coi- sas, mas nós as distinguimos porque podemos passar da aparência à realidade através de alguma noção ou imagem".

Deste modo, a aparência de um ambiente demonstra, de certo modo, as necessidades referentes aos usos aos quais se destina, mas sem que, no entanto sua realidade seja visível aos olhos daqueles que a vivenciam. Vê-se aquilo que se quer ver. $\mathrm{O}$ ambiente retratado sob este ponto de vista condiz com uma esfera de pensamento real acerca da realidade.

Neste direcionamento, Moscovici (2007) coloca a esfera do pensamento enquanto um ambiente, pois se constitui de uma atmosfera social e cultural, onde as experiências são somadas às realidades predeterminadas por convenções sociais. Então, os pensamentos imaginados, que são as representações sociais, se "constituem em um ambiente real, concreto" (p. 40) uma "realidade sui generis" (p. 41). A compreensão do real e da realidade leva ao entendimento de que "as formas principais de nosso meio ambiente físico e social estão fixas em representações sociais" (MOSCOVICI, 2007, p. 42) quase permanentes que se cristalizam através dos tempos e acabam até mesmo por moldar as pessoas, ainda que estas não percebam.

O Planejamento Urbano é pensado e estruturado com a intenção de organizar o espaço urbano para fins e usos predeterminados. Sendo assim, tem o poder de alterar o uso e o destino dos diferentes espaços de maneira a garantir os interesses sociais e econômicos de uma área. Entretanto, tem também o poder de influenciar, ainda que tal influência passe despercebida, a maneira de viver das pessoas. Para melhor compreensão, considera-se oportuna a discussão dos referenciais que organizam o Planejamento Urbano de modo geral, privilegiando alguns apontamentos dentro do que se entende por Planejamento Urbano no Município de Araucária / PR.

\subsection{PLANEJANDO O ESPAÇO URBANO. O CONTEXTO DE ARAUCÁRIA / PR}

De modo geral, pode-se dizer que o desenvolvimento urbano acarreta o aumento do número de residentes e também do número de indústrias. Cada um destes necessita, por sua vez, de condições básicas para se manter e se desenvolver. Entretanto, se cada uma das partes escolher por conta própria o local onde fará suas instalações, a condição urbana corre grandes riscos de se tornar caótica, além dos danos que podem 
MOURA, N.; BAHL, M. Planejamento urbano e representações sociais...

ser causados ao ambiente. Na intenção de garantir a ocupação ordenada do espaço e de diminuir os danos ao ambiente urbano entra em cena uma das tarefas do Planejamento Urbano: a elaboração das Leis de Zoneamento, Uso e Ocupação do Solo, que visam promover uma melhor adequação do espaço urbano.

O Planejamento Urbano está previsto na Constituição Federal de 1988, em seu artigo 182, prevê como sua meta e função "ordenar o pleno desenvolvimento das funções sociais da cidade e garantir o bem-estar de seus habitantes". (BRASIL, 1988, art. 182). Além das funções sociais, deve-se também levar em conta os aspectos naturais, pois o ambiente físico se constitui no alvo e no processo do zoneamento, neste sentido o planejamento urbano deve resultar, portanto, na conservação dos recursos naturais, entendidos como o uso apropriado do meio ambiente dentro dos limites capazes de manter sua qualidade e seu equilíbrio em níveis aceitáveis (MOTA, 1999).

Então, focalizando as atenções sobre o Planejamento Urbano e centrando os interesses no Município de Araucária, é conveniente descrever como seus diri- gentes encaram a elaboração de tão importante lei, uma vez que esta consiste em seu 'autorretrato', pois delimita e define seu modo de encarar e agir com o espaço urbano que lhe diz respeito. No entanto, entende-se que para que o leitor compreenda o contexto do município em questão, é necessário que conheça um pouco mais sobre a evolução histórica e econômica dele para que o situe no tempo e no espaço dentro da evolução do país e do Estado do Paraná. Neste sentido, segue um reporte aos aspectos de maior interesse para a presente abordagem, sobre a evolução e desenvolvimento do Município de Araucária.

Situado na Região Metropolitana de Curitiba (RMC), no Primeiro Planalto Paranaense, ocupa uma área de 460,85 km², na altitude de $857 \mathrm{~m}$ acima do nível do mar (figura 1). A região onde se situa o Município de Araucária era ocupada por índios da tribo dos tinguis. Com o descobrimento de ouro de aluvião, muitos interessados em garimpar se instalaram na região próxima ao rio Iguaçu, local onde foi instalado um pequeno porto de canoas conhecido como Passo das Laranjeiras. A partir de então, o aglomerado de pessoas foi ganhando forma.

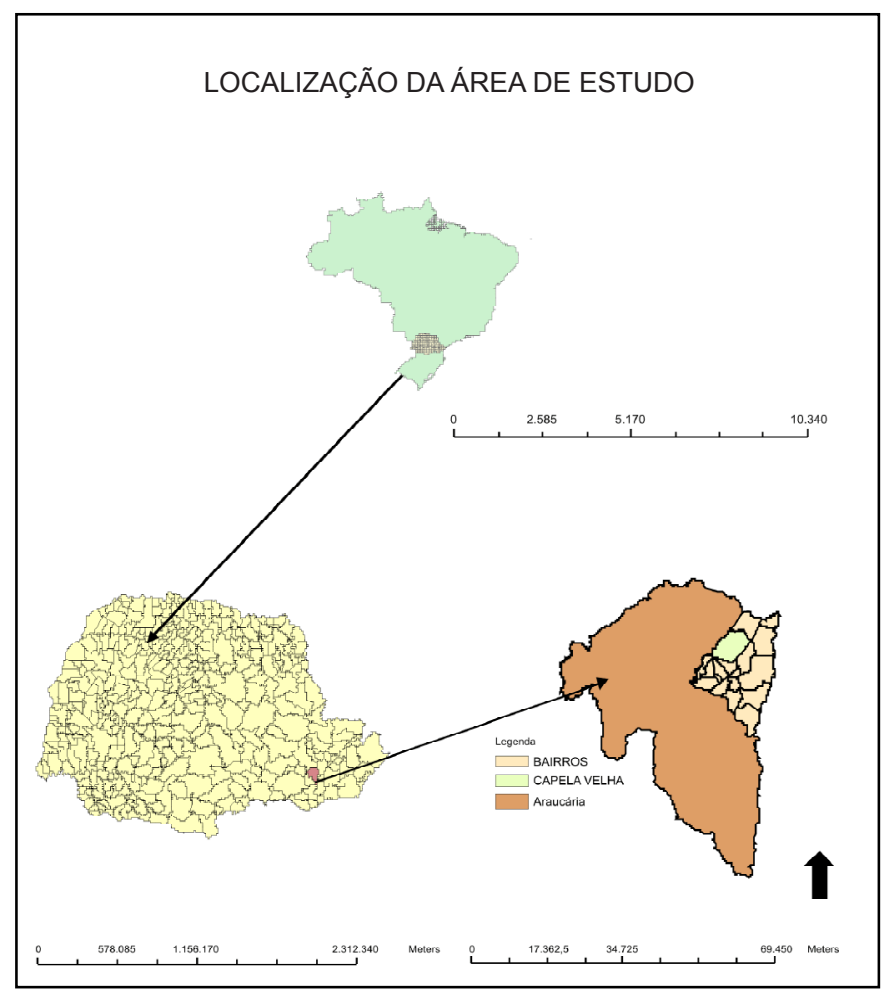

FIGURA 1 - LOCALIZAÇÃO DA ÁREA DE ESTUDO

FONTE: SMPL.

ELABORAÇÃO: MOURA, N. (2008). 
MOURA, N.; BAHL, M. Planejamento urbano e representações sociais....

A região era passagem obrigatória aos que iam de Curitiba até a Lapa, fato explorado pelos habitantes para vender sua pequena produção agrícola excedente, o que acarretou um pequeno desenvolvimento econômico aos moradores (ARAUCÁRIA, 2003a).

O crescimento econômico proporcionou a abertura de mercado para outras fontes geradoras de emprego para a população, como as olarias, cerâmicas, moinhos, fábrica de palhões, molho de tomate, entre outras. O desenvolvimento econômico do Município se deu com maior ênfase durante a década de 1970, assim como também o foi em todo o Estado do Paraná devido à vinda de indústrias, sobretudo as do complexo metalmecâncio concentradas em Curitiba. Tal fato gerou um surto de desenvolvimento no setor industrial que possui características diferenciadas e inovadoras em relação aos movimentos anteriores que tinham características locais. Segundo Firkowski (2001, p. 25), tal diferenciação se deve ao foco de tais empreendimentos, uma vez que estes se originaram no sentido de atender a outros mercados (nacionais e internacionais), com controle acionário externo, esvaindo a estrutura local que existia outrora.

A evolução econômica do Município se deu em três fases. A primeira no início do século XX, estimulada pelo consumo interno do Município. Eram olarias, serrarias, cervejarias, engenhos de mate e fábricas de barricas, utilizadas para o transporte do mate beneficiado. A segunda fase se constitui pela produção de tecido de linho, pela fábrica São Manoel, filial em Araucária da matriz de São Paulo, a São Patrício. A terceira e grande fase, deu-se com a implantação da Refinaria Presidente Getúlio Vargas, pela Petróleo Brasileiro. Este fato provocou a organização e implementação do Centro Industrial de Araucária (CIAR), ocasionando rápida industrialização (ARAUCÁRIA, 1999, p. 21).

Com base nos dados gerais de sua história e de sua evolução econômico-social, pode-se partir rumo às considerações sobre seu entendimento quanto ao Planejamento Urbano e suas atribuições.

Em consonância com a Constituição Federal de 1988, o Município de Araucária tem elaborado seu Plano Diretor (P. D.), que contém determinações que garantem a aplicação e consolidação de metas de planejamento urbano, bem como de zoneamento, uso e ocupação do solo. Segundo este documento, o "Plano Diretor é o instrumento básico da política de desenvolvimento e expansão urbana do Município, abrange a totalidade do território municipal e integra o processo de planejamento [...]" (ARAUCÁRIA, art. 20, Lei 005/2006) Para tanto, a política urbana municipal estabelece três princípios por ela considerados fundamentais (art. $5^{\circ}$ ), sendo:
I - Função social da cidade e da propriedade;

II - Sustentabilidade e preservação do patrimônio sócio-ambiental;

II - Gestão democrática.

De acordo com o artigo $6^{\circ}$ da referida Lei a função social corresponde ao direito à cidade para todos os seus cidadãos, que compreende os direitos à terra, moradia, saneamento ambiental, meio ambiente, infraestrutura, serviços públicos, educação, saúde, segurança pública, transporte coletivo, mobilidade urbana e acessibilidade, trabalho, cultura, lazer e informação, nas áreas urbana e rural, cabendo à política de desenvolvimento municipal ordenar o pleno desenvolvimento e uso social justo, "ecologicamente equilibrado e diversificado de seu território, de forma a assegurar o bem-estar equânime de seus habitantes". (ARAUCÁRIA, 2006, art. 12). A função social da propriedade é cumprida quando a função social da cidade também o for, e isto ocorre na medida em que seja utilizada para: I - habitação, especialmente as de interesse social; II - atividades econômicas geradoras de emprego e renda; III - proteção ao meio ambiente; e IV - preservação do patrimônio cultural. Além destes a propriedade deve atender simultaneamente os quesitos: I - intensidade de uso adequado à disponibilidade de infraestrutura, de equipamentos e de serviços; II - uso compatível com as condições de preservação da qualidade do meio ambiente, da paisagem e do patrimônio local; III - aproveitamento e utilização compatíveis com a segurança e saúde de seus usuários e vizinhança; IV - utilização adequada do terreno. (ARAUCÁRIA, 2006 , art. $7^{\circ}$ e $8^{\circ}$ ). Cabendo estas normatizações serem garantidas na Lei de Zoneamento, Uso e Ocupação do Solo.

Neste sentido, faz referência ao que a Lei 584/81, em seu artigo $2^{\circ}$, argumenta sobre o que se entende no Município como sendo a função do zoneamento urbano contido em seu Planejamento. Para o Poder Público Municipal o zoneamento urbano é entendido como "[...] a divisão do município em zonas de usos diferentes segundo sua precípua destinação" (Lei 584/81, art. $2^{\circ}$ ). A Lei citada é anterior à C. F. (Constituição Federal). Entretanto, encontra-se em consonância com a mesma. Visto desta maneira, pode-se verificar o entendimento do zoneamento enquanto um instrumento que tem por finalidade a divisão do espaço em zonas delimitadas nas quais se tem usos predeterminados de maneira a garantir o bem-estar público e social, além dos fatores econômicos implícitos como a industrialização. 
MOURA, N.; BAHL, M. Planejamento urbano e representações sociais...

\section{AS REPRESENTAÇÕES SOCIAIS E A ANÁLISE DO URBANO}

Analisar a cidade de Araucária e mais especificamente seu Planejamento Urbano é tarefa que inspira a utilização das representações sociais, pois seu processo de urbanização incita polêmicas quanto à adequação do espaço entre os usos residencial e industrial, uma vez que tais usos são distintos e não equivalentes, mas que, no entanto são paralelos, próximos e um gera implicações ao outro.

O conceito de Representações Sociais de Moscovici (2007) se constrói numa tentativa de dar conta da nova gama de fenômenos que se mostravam no mundo contemporâneo, afastando-se aí da sociologia e construindo um espaço psicossociológico próprio (SÁ, 1996). A construção de tais espaços exprime o que Moscovici (2007) afirma serem as representações sociais, colocadas como conjuntos de conceitos, afirmações e explicações que devem ser considerados como "teorias" do senso comum.

Utilizando-se dos conceitos colocados por Moscovici (2007) se procurou encontrar elementos que para a análise do fenômeno urbano, delimitando o conjunto dos fatos às representações sociais oriundas das ações do Planejamento Urbano dentre os moradores do bairro. Sendo desta maneira, as noções de familiar e não familiar foram elencadas enquanto elementos a serem discutidos e avaliados durante o processo de análise dos dados empíricos, levando em conta a maneira com que os mesmos eram ancorados e objetivados no universo de conhecimento dos moradores, ou o universo consensual, inferindo sobre as maneiras e modos por meio dos quais os mesmos se utilizavam dos elementos advindos do conhecimento acadêmico ou normatizado, ou o universo reificado.

Deste modo, se julgou pertinente a utilização da Teoria das Representações Sociais na análise do Urbano, pois ela pode dar sustentação ao intersubjetivo presente nas relações sociais. Pelo fato de se tratar no âmbito das relações sociais, optou-se pela utilização de um conceito que pudesse dar conta deste contexto. A escolha foi pelo conceito de espaço de relações proposto por Bourdieu (2003) pelo fato de este ser um conceito de espaço que envolve o social. Nele se travam as relações entre o poder, aqui representado pelas ações do poder público municipal e os moradores. Esta relação encontra-se inserida em meio à prática social dos moradores e suas vidas cotidianas. Com base nestes conceitos, buscou-se estruturar o espaço em que se desenvolvem e atuam as representações sociais no bairro.

\section{O ESPAÇO DE RELAÇÕES: PLANEJAMENTO URBANO X SOCIEDADE}

Numa tentativa de melhor elucidar as colocações, percebe-se a necessidade de descrever a intenção que se tem com o espaço de relações. Para o presente estudo de caso, idealizou-se um espaço de relações produzido pela interação do poder e da prática social, numa mistura harmônica. O resultado de tal mistura recai em um campo simbólico, que aqui será entendido como espaço, espaço este que tramita no âmbito do social, ou, das relações sociais.

O espaço gerado durante este processo é simbólico e se materializa por meio das relações que se consubstanciam em seu interior. Então, este espaço de relações é simbólico e material simultaneamente, pois ao mesmo tempo em que sua existência é reconhecida, sua materialidade é impossível de ser tocada ou delimitada no mundo real. Ele faz parte da vida cotidiana, em que entram em cena diferentes opiniões e condutas, que nem sempre se organizam em torno dos mesmos entendimentos. O que se propõe é que nele coexistam as representações sociais do ambiente devido a seu caráter consensual.

O espaço de relações ao qual se faz referência se estabelece com base nas representações sociais fundado na intersubjetividade inscrita na prática social, ou seja, nas ações e reações produzidas durante o movimento e surgimento das representações sociais ocorridos na vida cotidiana. É constantemente atravessado por ações de poder, que representam um universo diferenciado daquele da vida cotidiana (universo consensual), ou seja, o universo reificado.

Tem-se então, duas categorias implícitas neste espaço de relações: a prática social e o poder. A interação entre estas duas categorias é que vai gerar o espaço ao qual se refere, pois à medida que os dois universos - reificado e consensual - são confrontados abrem-se lacunas, espaços, onde a vida de relações se efetua e se concretiza, lugar em que o reificado torna-se elemento de discussão ao consensual, que irá, por sua vez, procurar uma maneira de ancorá-lo em fatos passados para que este se transforme em parte da prática social. Sendo assim, pode-se dizer que este espaço é dual e dinâmico e que pode ser representado na relação poder x prática social. Dentro destas sinalizações, pode-se argumentar que de modo geral o poder se legitima pelas ideias inerentes à prática social dos grupos. Tais ideias, por sua vez, constituem-se na essência do poder, pois dão-lhe o caráter de justiça ou de inevitabilidade que permitem que seja exercido em 
MOURA, N.; BAHL, M. Planejamento urbano e representações sociais....

atos rotineiros, com assepsia da normalidade. Então, é na prática social que o poder se legitima, consolida-se e se faz sentir, é ela quem busca tentar dar existência às coisas, garantindo a usurpação pela força do poder. Neste contexto, o discurso opera como fator determinante, pois sua eficácia garante também a eficácia do enunciado proferido (BOURDIEU, 1996).

De acordo com Bourdieu (1996) para que o poder se concretize em um grupo é iminente que a força do discurso ganhe status dentro do contexto social, fazendo-se valer pela força do poder atribuído àquele que o profere, fazendo com que as lutas sociais se movimentem pela imposição de percepções e de categorias de percepções, num sentido dialético de existência.

Neste sentido, convém a colocação do elemento 'poder' como integrante do espaço de relações gerado nas representações sociais do ambiente urbano, pois permite a inserção de conceitos reificados num universo consensual bem delimitado, no caso, o espaço urbano. Valendo lembrar ainda, que o poder se faz presente de maneira concisa no âmbito da prática social em que é exercido. Na pertinência retratada, o poder e suas relações são fatos operantes em dado ambiente, que com suas características peculiares, fazem-se destacar no quadro urbano municipal. Outro ponto que merece ser lembrado é o fato de que o poder que atua na área de estudo é o poder institucionalizado representado pelo poder municipal, que embora presente cotidianamente, nem sempre é percebido, passa como invisível aos olhos do grupo social e na maioria de suas práticas, que se constituem no segundo elemento do espaço de relações proposto.

A realidade da vida cotidiana existe em diferentes modalidades. Ela se organiza em torno dos corpos e de suas respectivas noções temporais. Entretanto, o cotidiano, vez ou outra, é inundado por realidades que fogem à normalidade, fato que faz com que esta seja aprimorada e ampliada constantemente. Berger \& Luckmann (1985, p. 39) argumentam que a realidade mais próxima é a realidade da vida cotidiana, pelo fato de estar ao alcance das mãos dos indivíduos e que por eles pode ser manipulada. É esta realidade, a que pode ser manipulada, que foi trabalhada. Ela permite a análise da prática social enquanto parte integrante das representações sociais. O interesse maior ficou centrado nas resultantes desta prática social, ou seja, nas realidades cotidianas inerentes ao senso comum, que "contém inumeráveis interpretações pré-científicas e quase-científicas sobre a realidade cotidiana admitida como certas pelas populações que as constroem". (BERGER; LUCKMANN, 1985, p. 37).

Este apontamento lembra o que escreve Moscovici (2007) sobre o senso comum, por ele chamado de universo consensual. Para o referido autor, o universo consensual encontra-se repleto de conceitos que emergem para este universo através do reificado e também pela própria prática cotidiana, em outras palavras, pela prática social. É na prática social que os indivíduos manipulam não só a sua realidade, mas entram em contato com realidades estranhas às suas. Além de se depararem com a realidade da sociedade de modo geral e com a da qual fazem parte. No universo consensual da prática social dialogam opiniões e concepções, inseridas em representações sociais. Tais representações sociais existem meio a espaços e tempos que tornam possível a constituição de espaços de representação.

A prática social como integrante do espaço de relações planejamento urbano $x$ sociedade se fortalece pelo fato de que nela é que se constroem as relações, tanto as de poder, como as sociais. Por este motivo é que se constituem em elemento de grande valia à constituição da proposta para um espaço de relações, no qual o poder e a prática social são o cimento e a argamassa para sua materialidade. Para a concretização da proposta, foram coletados dados junto aos dois segmentos que compõem tal espaço de relações: o poder, representado pelas Secretarias de Planejamento Urbano e de Meio Ambiente, e a prática social, representada pelos moradores do bairro. As colocações dos entrevistados se constituíram no trabalho de pesquisa empírica e serviram como base à elaboração das figuras e análises. As pesquisas foram abertas e semiestruturadas, nas quais os entrevistados puderam falar livremente sobre o tema e colocar suas reais opiniões. As conversas foram gravadas e posteriormente transcritas e utilizadas no trabalho em gabinete.

\section{ZONEAMENTO URBANO: ORDENAR PARA DESENVOLVER}

As análises que se configuraram como necessárias para o entendimento da problemática discutida com todos os seus pormenores teve como prerrogativa inicial a avaliação do universo reificado que se legitima por meio das ações de poder exercidas pelas Secretarias Municipais de Planejamento Urbano e de Meio Ambiente. Sendo assim, foi entrevistado um representante de cada uma das referidas secretarias, com a finalidade de obter opiniões que permitissem uma avaliação mais precisa para a compreensão dos conflitos de uso ocorridos no bairro Capela Velha. Então, a primeira Secretaria a ser avaliada foi a de Planejamento Urbano (SMPL). 
MOURA, N.; BAHL, M. Planejamento urbano e representações sociais...

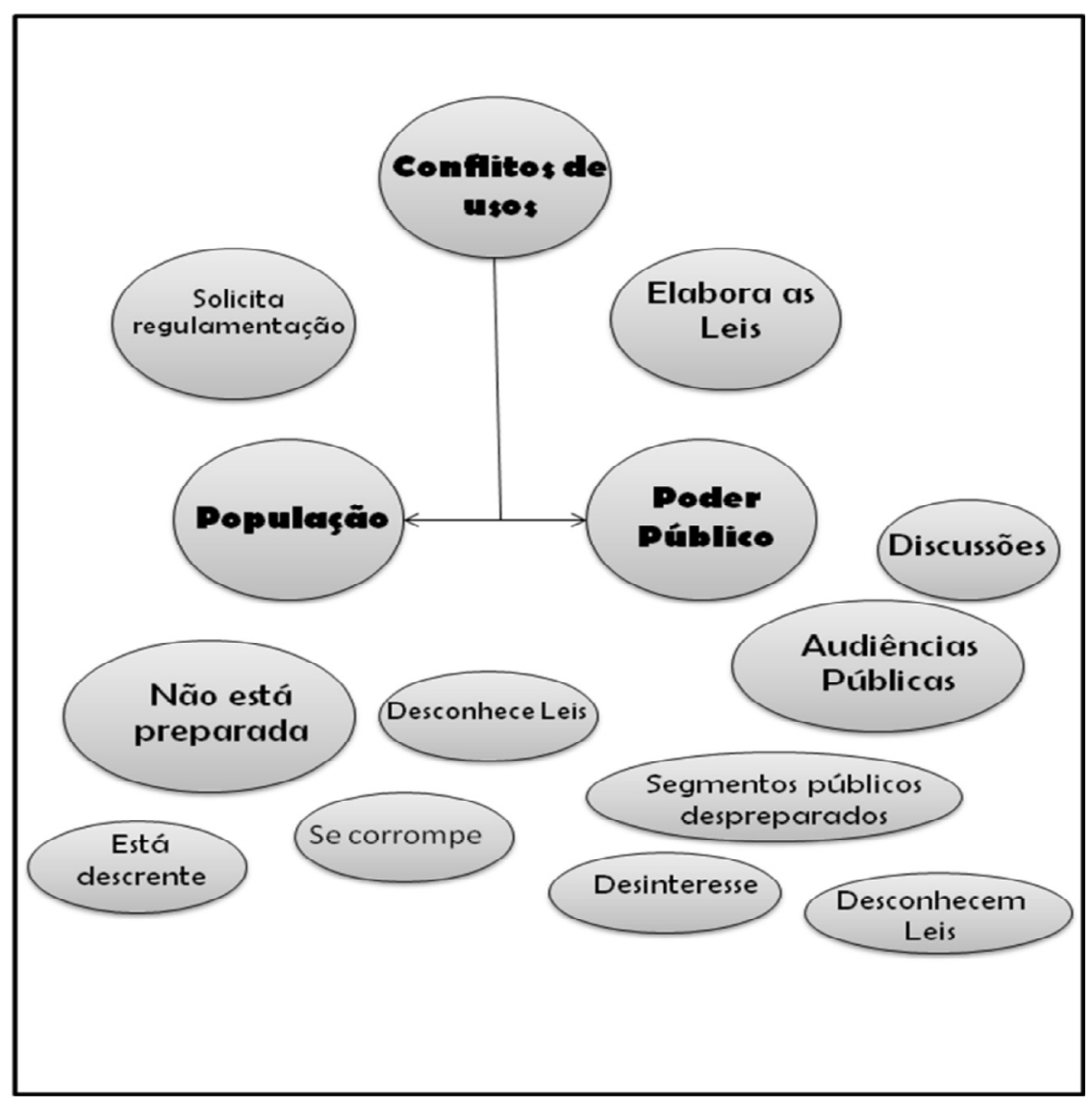

FIGURA 2 - NÚCLEOS REPRESENTATIVOS: PLANEJAMENTO URBANO. ARAUCÁRIA / PR

FONTE: PESQUISA DE CAMPO (2008).

ORGANIZAÇÃO: MOURA, N.

Seu representante posicionou dentro de sua fala o entendimento da Secretaria perante a temática, evidenciando pontos que se configuraram em elementos centrais, ou núcleos de representação. Estes foram organizados e apontados na figura 2. Na figura se podem verificar centralidades que emergem no discurso a cada nova frase proferida. Ao redor de cada núcleo, podese verificar pontos que abrangem mais do que simples colocações articuladas no momento do discurso.

Eles representam um posicionamento, uma maneira de dimensionar o problema próprio de quem ocupa uma posição de relativa importância dentro do contexto em que emanam os conflitos, no caso, os conflitos de uso, ocorridos no bairro Capela Velha, integrante do Quadro Urbano Municipal de Araucária, especificamente, entre zona residencial e zona industrial. A figura pode ser explicada da seguinte maneira: as ações do Poder Público geram conflito de usos entre a população e as indústrias. Na tentativa de tentar resolver o impasse o
Poder atua como elemento que elabora e funda leis que têm por objetivo equacionar os conflitos. A atual gestão se diz inovadora em sua maneira de lidar com a elaboração das Leis, em especial a do novo Plano Diretor em fase de votação, utilizando-se de metodologias inovadoras, como a de buscar representatividade nas classes sociais e nos diversos segmentos que compõem o Poder público. No entanto, ao fazer isso, a Comissão do Plano Diretor se deparou com situações inusitadas em que se evidenciaram o despreparo tanto da população como dos próprios segmentos convidados a fazerem parte do processo de discussão.

O representante da Secretaria Municipal de Meio Ambiente (SMMA) do mesmo modo que o primeiro também colocou o posicionamento da Secretaria na qual trabalha. Do mesmo modo que a primeira secretaria analisada, o depoimento do entrevistado trouxe apontamentos que trafegaram no entorno de núcleos representativos que foram mapeados na figura 3 . 
O ponto principal em seu discurso se refere à ligação de complementaridade entre o zoneamento urbano e a SMMA, onde situaram os pontos considerados, por ele, como sendo os de maior importância dentro da temática abordada. Transitando ao redor do zoneamento, encontram-se os conflitos de uso entre o industrial e o residencial nos quais a SMMA atua como mediadora entre os ânimos, buscando sempre apaziguar a situação. Também ao redor do zoneamento e ligada ao conflito de usos, encontra-se o sentimento de insatisfação da população e das indústrias, ambas querendo ter seus direitos garantidos legalmente.

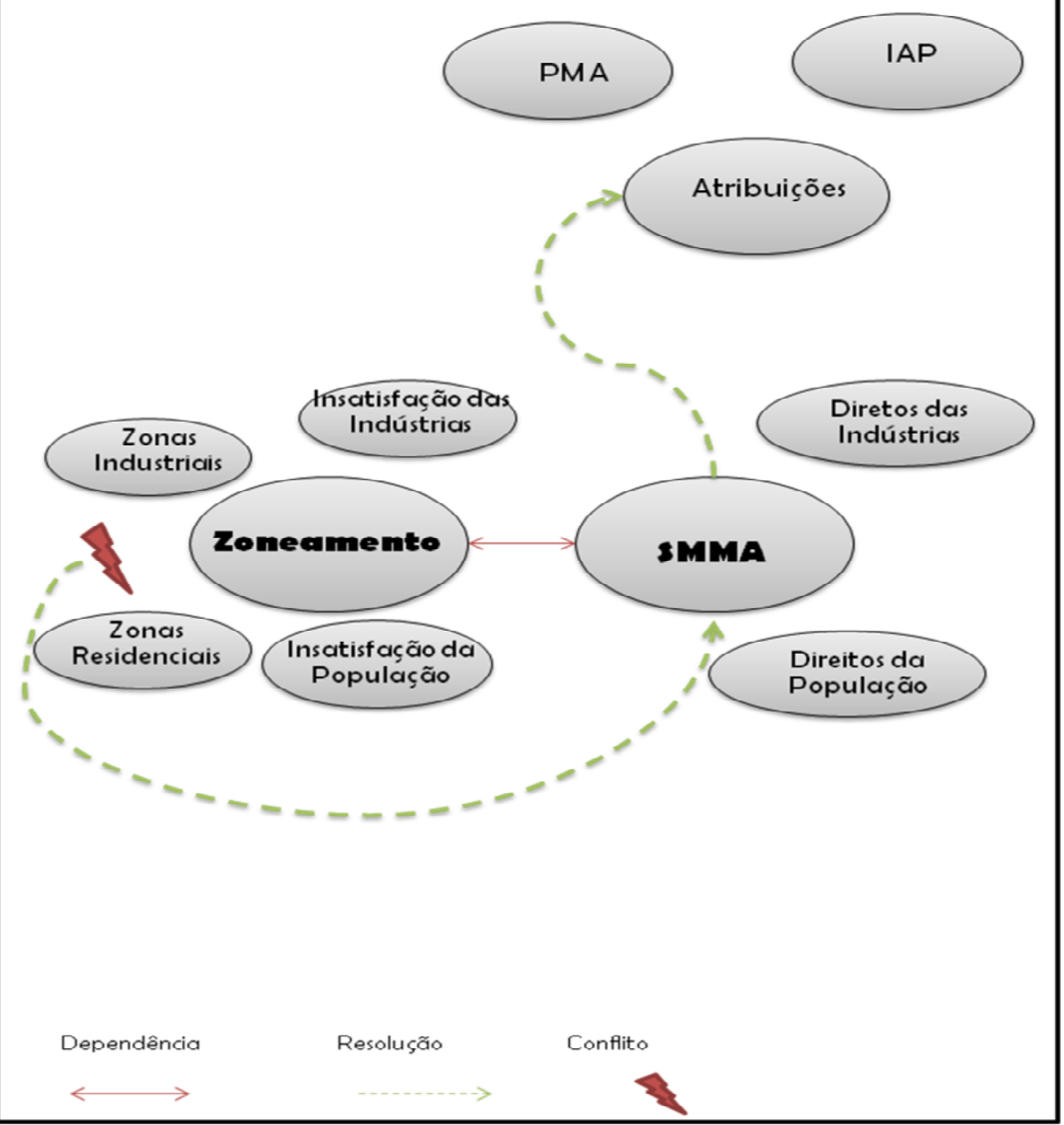

FIGURA 3 - NÚCLEOS REPRESENTATIVOS: SECRETARIA MUNICIPAL DE MEIO AMBIENTE. ARAUCÁRIA/PR

FONTE: PESQUISA DE CAMPO (2008).

ORGANIZAÇÃO: MOURA, N. (2008).

Neste contexto, a atuação da SMMA, segundo o entrevistado, ocorre através da colocação de suas atribuições nos usos dos instrumentos legais de que dispõe para garantir os direitos de um e de outro, tornando de conhecimento público as atribuições inerentes a si, enquanto órgão legal.

Os direitos das indústrias e da população são feridos no conflito de usos causados pela proximidade entre as zonas, cabe a SMMA a busca por alternativas à solução destes sem, no entanto, radicalizar demais suas atitudes a fim de não causar a evasão das indústrias envolvidas nem de aumentar ainda mais a insatisfação popular. Para o entrevistado, a proximidade entre as zonas é apontada como um dos "grandes problemas" dentro do Quadro Urbano Municipal e a solução para o mesmo foi encontrada na mudança do traçado do 
MOURA, N.; BAHL, M. Planejamento urbano e representações sociais...

zoneamento, numa tentativa de "filtrar o barulho e o movimento" das zonas industriais, criando uma zona de serviços, com atividades de menor impacto que trariam a valorização dos imóveis e tendo como intenção também a expulsão indireta dos moradores destas áreas devido a tal valorização.

Tendo como base estes apontamentos iniciais, fez-se iminente saber e analisar os discursos da população envolvida, suas razões e posicionamentos em relação ao conflito de usos que se dá em seu ambiente de vivência.

\section{OPINIÕES QUE SE CRUZAM}

Para que se pudesse elaborar uma análise mais coerente acerca dos dados levantados durante as entrevistas, optou-se por realizar uma divisão entre os elementos da entrevista. A primeira parte retrata o lugar e a segunda, como os entrevistados vivem neste lugar.

\subsection{O LUGAR ONDE EU VIVO}

Falar sobre o lugar consiste em uma tarefa que nem sempre as pessoas se dão ao trabalho de fazer. Ao falar sobre o lugar, sobre o bairro Capela Velha, os entrevistados deixaram, além de marcas pessoais, marcas comuns em seus discursos. Para efeitos de melhor entendimento e compreensão das intenções do presente trabalho, optou-se pela elaboração de um mapeamento dos temas mais recorrentes nos depoimentos, a fim de elucidar com maior clareza seus aspectos mais relevantes. Assim sendo, na figura 4, buscou-se refletir os dados de maior relevância para que os objetivos finais fossem alcançados. Na figura, foram mapeados os dados que se fizeram presentes com maior intensidade. As cores foram utilizadas para diferenciar o valor que foi atribuído a cada quesito. Analisando os resultados das entrevistas, pode-se avaliar que eles podem ser divididos em três grupos: 1) aqueles que mencionaram gostar do lugar; 2) aqueles que mencionaram gostar, mas que o criticaram; e, 3) aqueles que mencionaram não gostar e o criticaram.

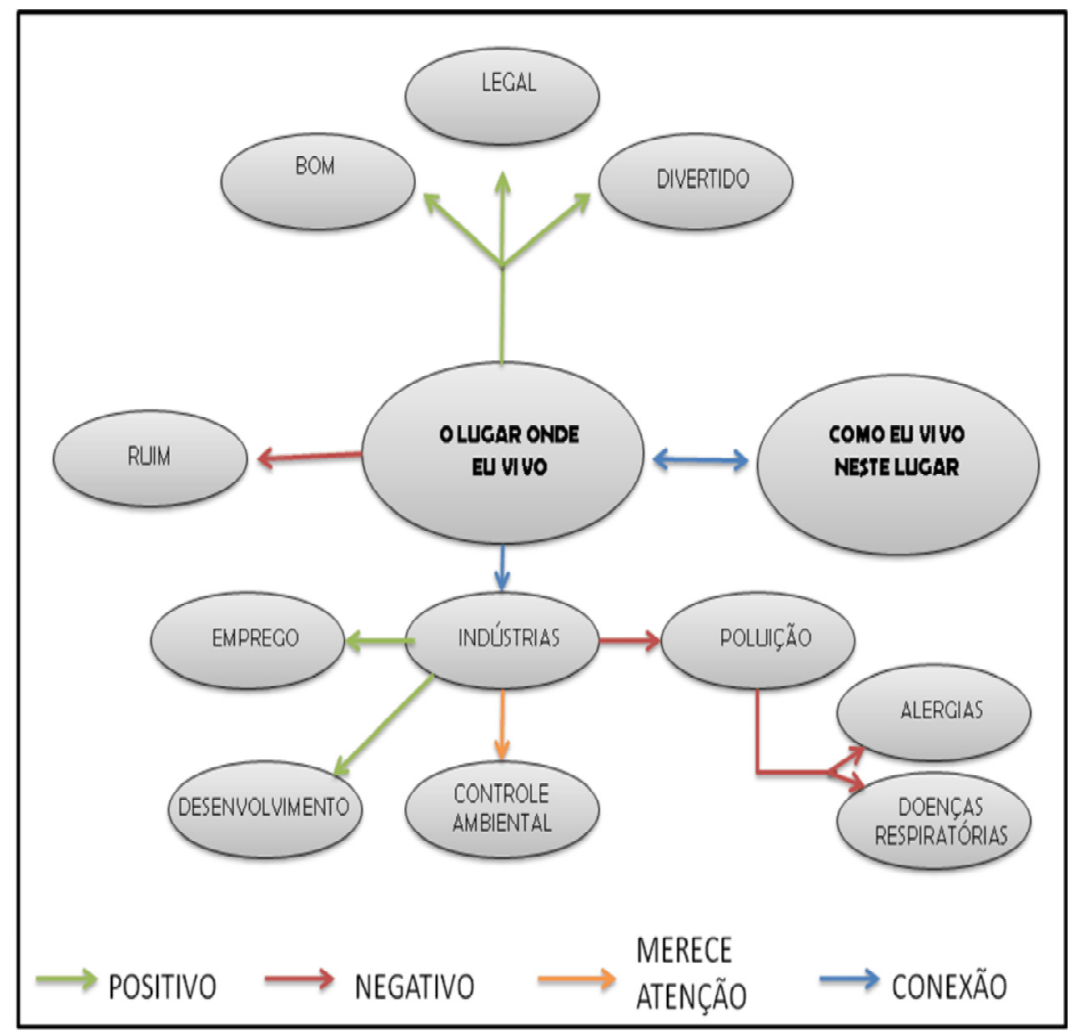

FIGURA 4 - MAPEAMENTO DAS ENTREVISTAS - 1

FONTE: PESQUISA DE CAMPO (2008).

ORGANIZAÇÃO: MOURA, N. (2008). 
Começando por aqueles que mencionaram apenas gostar do lugar sem Ihe atribuir crítica alguma, pode-se observar logo de início a maneira como estas pessoas descreveram sua história de vida. Em geral, são migrantes vindos de outras partes do país, e também do próprio Estado, que vieram para Araucária com a expectativa de encontrarem melhores condições de vida do que as que tinham em seu lugar de origem. Os entrevistados deste grupo manifestaram reconhecer a existência dos problemas ambientais ocorridos no bairro devido ao conflito de usos. Entretanto, avaliaram como sendo boa a condição de vida, demonstrando um sentimento de pertença ao lugar, que muitas vezes faz sentir a necessidade de defender o "seu" lugar contra tudo e todos que o agridam de alguma maneira. Este grupo, então, encontra-se numa dualidade em que os moradores tentam sempre encontrar justificativas aceitáveis para os problemas do bairro.

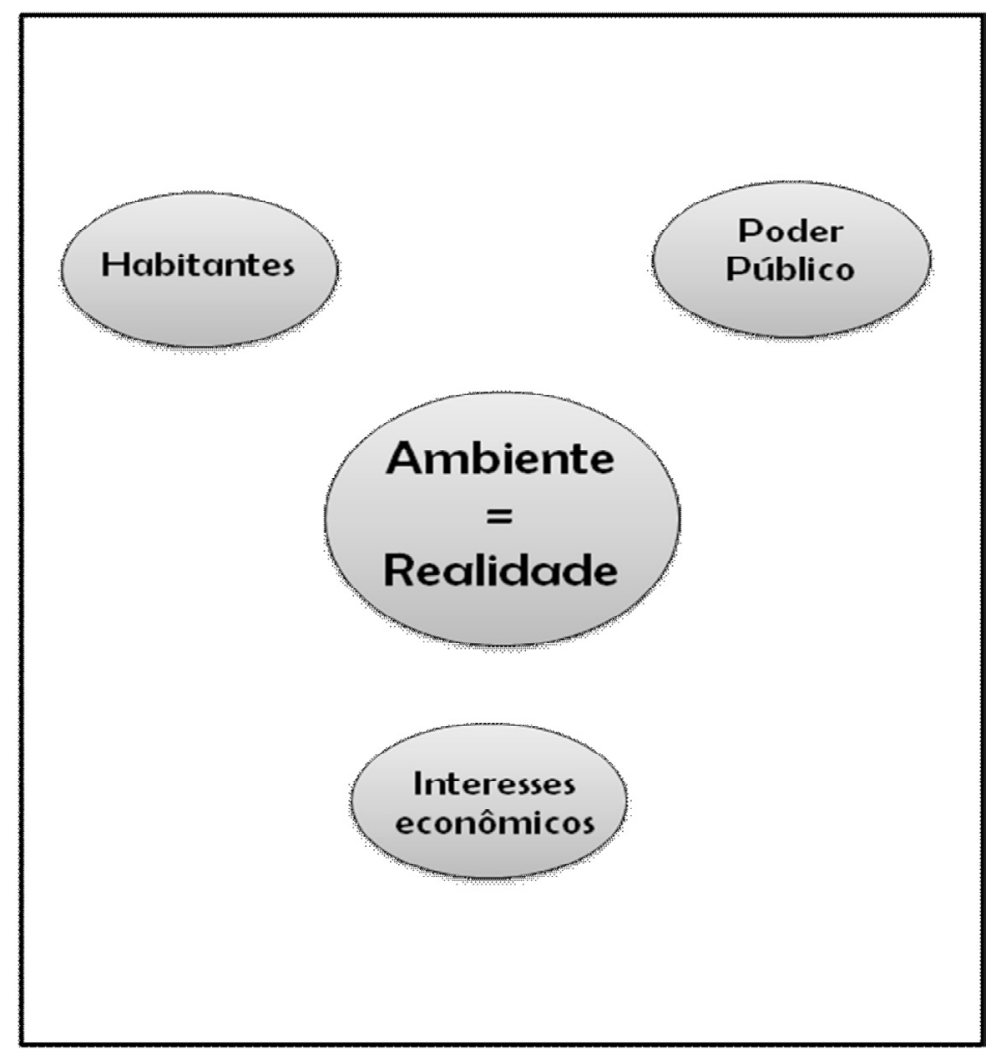

FIGURA 5 - NÚCLEO DE REPRESENTAÇÃO - GRUPO 1

FONTE: PESQUISA DE CAMPO (2008).

ORGANIZAÇÃO: MOURA, N. (2008).

A rotina faz com que os fatos pareçam mais aceitáveis, entretanto, o questionamento leva ao pensar sobre o assunto e o que era rotineiro deixa de ser e se torna uma ilusão, fazendo com que a imagem da realidade fique distinta entre as outras imagens presentes no repertório mental (MOSCOVICI, 2007). Agindo assim, este grupo de entrevistados refletiu a dualidade de opiniões presentes e também o conhecimento e reconhecimento que eles têm das condições ambientais do bairro (BOURDIEU, 2003). Tal fato os leva a refletir sobre o problema, sem, no entanto, fazer com que suas opiniões mudem.
Neste contexto de dualidades, pode-se retirar uma primeira síntese, ou um primeiro núcleo de opiniões demonstrado pela figura 5. A figura deixa transparecer a fragilidade do ambiente enquanto realidade manipulada pelos habitantes, pelas indústrias e pelo poder público. Todos agem sobre ele, com interesses e fins que atendam às suas necessidades. As indústrias trazem desenvolvimento e emprego; o poder público atua sobre o lugar para melhorar as condições de vida da população, e os habitantes fazem uso dos benefícios trazidos por um e outro. 
MOURA, N.; BAHL, M. Planejamento urbano e representações sociais...

Entretanto, cabe questionar quais as consequências das ações do homem ao meio? Neste ponto, destacase o segundo grupo de entrevistados, o dos que mencionaram gostar do lugar, mas criticaram as condições ambientais e sociais a que estavam expostos, refletindo sobre o problema e apontando possíveis soluções por parte do poder público e das instituições privadas, que na visão destes, teriam a obrigação de tomar atitudes coerentes para solucionar os problemas, de maneira a não afetar a população e o meio, ou seja, medidas que priorizem também estas questões.

A característica mais marcante deste segundo grupo é seu caráter reflexivo e autocrítico. Nele, os entrevistados não deixaram de opinar quanto ao prazer que sentiam em morar no bairro, mas também não deixaram de salientar os difíceis "entretanto" e "mas". Estas duas conjunções denotam outro argumento, ou seja, outra face da moeda. Mostram que o real, nem sempre condiz com a realidade. Neste grupo, também foram encontrados núcleos de representação, colocados na figura 6 , que procura evidenciar os pontos destacados, salientando suas interconexões.

O que se pode notar é que os entrevistados procuraram deixar clara sua opinião, buscando elementos que dessem base a ela, ou seja, procuraram respaldar suas opiniões em elementos científicos, mas ao mesmo tempo, não deixaram de colocar também seu ponto de vista pessoal, ou de suas necessidades pessoais. Com base nisto, pode-se ter uma segunda síntese. Os entrevistados deste grupo demonstraram ser donos de opiniões fundadas em elementos científicos, mas em seu cotidiano, em sua prática social, acabaram por relegar estas questões ao poder municipal ou aos interesses privados.

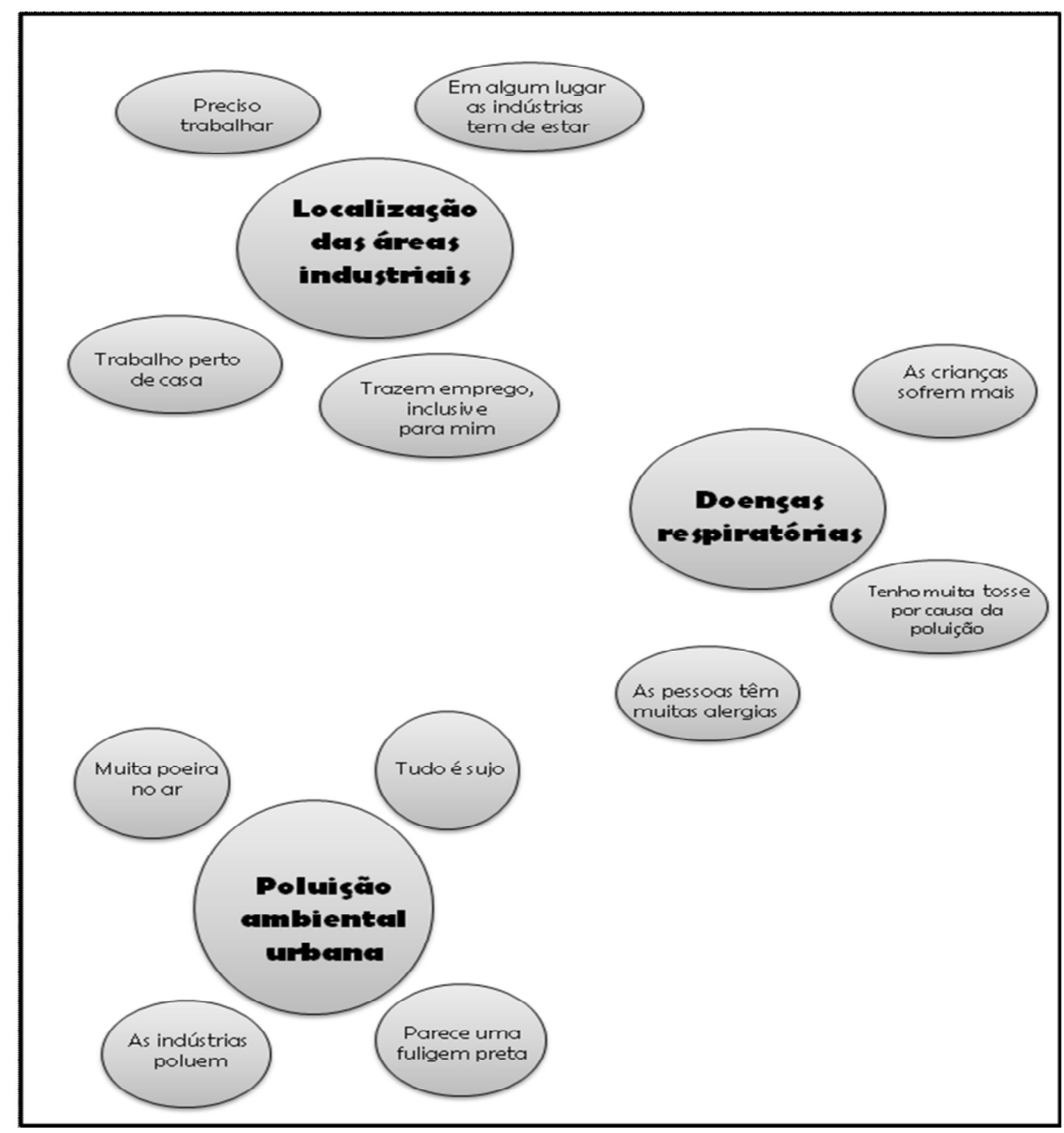

FIGURA 6 - NÚCLEOS REPRESENTATIVOS - GRUPO 2

FONTE: PESQUISA DE CAMPO (2008).

ORGANIZAÇÃO: MOURA, N. (2008). 
O terceiro grupo, por sua vez, destacou elementos relacionados com a vida pública e suas condições. Os entrevistados deste grupo têm em comum a falta de apego e afinidade com o bairro. Os argumentos utiliza- dos por eles para justificar tal posicionamento têm as mesmas bases: a poluição (barulho, mau-cheiro, poeira) e a violência, que foram considerados como os núcleos representativos do grupo, colocados na figura 7 .

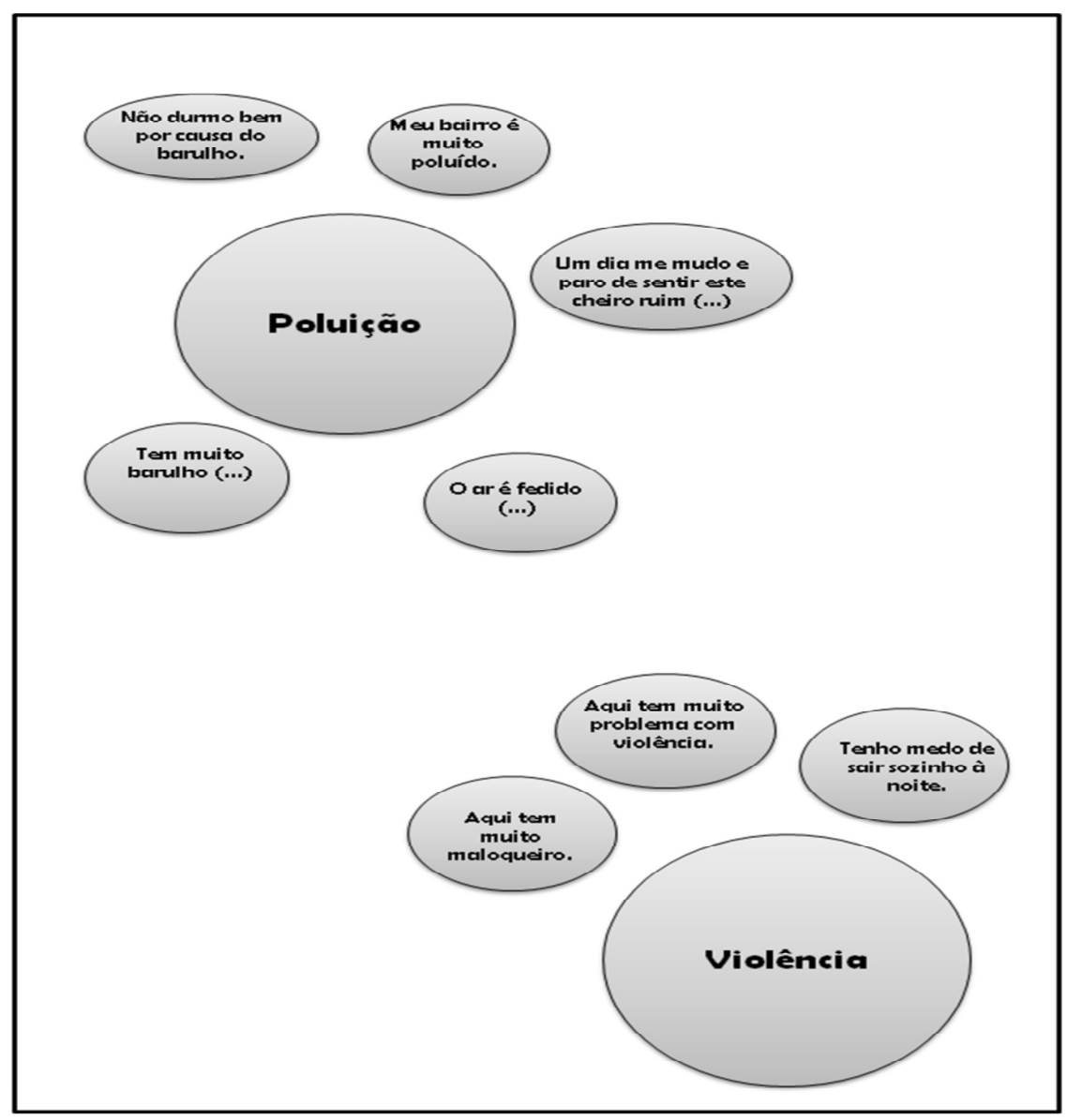

FIGURA 7 - NÚCLEOS REPRESENTATIVOS - GRUPO 3

FONTE: PESQUISA DE CAMPO (2008).

ORGANIZAÇÃO: MOURA, N. (2008).

Poluição e violência foram colocadas pelos entrevistados deste grupo como elementos que têm a mesma causa, ou seja, a instalação das indústrias no bairro. Sendo desta maneira, tudo parece estar ligado, de uma maneira ou de outra, à questão da formação do polo industrial no município, fator que gerou o conflito de usos, que aflige moradores e preocupa gestores há quase três décadas no Município. Estes fatos levam à segunda parte das avaliações representantes do universo consensual, que trata sobre o modo como as pessoas vivem no lugar.

\subsection{COMO EU VIVO NESTE LUGAR}

Gostar ou não gostar de seu lugar, de seu bairro, implica em definir o "como" se viverá neste bairro. As relações travadas no âmbito da prática social delimitam as estratégias de vida dos moradores: gostar das pessoas, do lugar, criticar as condições ambientais [...] são posturas que vislumbram o patamar em que se encontram as atitudes cotidianas ou o modo como se vive naquele lugar. As entrevistas deste grupo também foram mapeadas no intuito de se obter uma visualização dos quesitos a serrem abordados. Tal mapeamento se encontra na figura 8. 
MOURA, N.; BAHL, M. Planejamento urbano e representações sociais...

Basicamente, estabeleceram-se três possibilidades para avaliação, ou três grupos: a contraposição entre "gosto" e "não gosto", os problemas de saúde e o trabalho. Tais possibilidades encaminharam para a organização dos grupos de entrevistados, que seguem a mesma ordem. Sendo assim, o primeiro grupo analisa a contraposição entre o "gosto e o não gosto" do lugar. Situando seus depoimentos na vivência que possuem do bairro, os entrevistados deste grupo procuraram manipular a realidade vivida na intenção de justificar sua postura, ou seja, procuraram exprimir um "porquê" para o gostar ou o não gostar. Neste sentido, a esfera representativa dos entrevistados deste grupo se situa entre o real e o imaginário, ou ainda, entre o real e a realidade. Neste contexto o real não se apresenta como aquilo que é diretamente apresentado aos olhos, ele se camufla sob os olhares daqueles que o manipulam, transformando-se aí em realidade, isto é, aquilo que é de alguma maneira, concreto e que faz parte da experiência e da prática social dos indivíduos. Neste sentido, reiterase com o exposto por Moscovici (2007) quando o autor afirma que as experiências individuais e coletivas são somadas às realidades. Tais realidades podem ser prédeterminadas e desta maneira constituir um ambiente social próprio, assim, as representações sociais inerentes a este processo, passam a compor uma espécie de realidade manipulável, em que os indivíduos se sentem seguros. Neste ambiente, as representações transitam livremente, tendo a possibilidade de se transformar, circular, morrer, ou ainda, de surgir novamente com suas faces renovadas (MOSCOVICI, 2007).

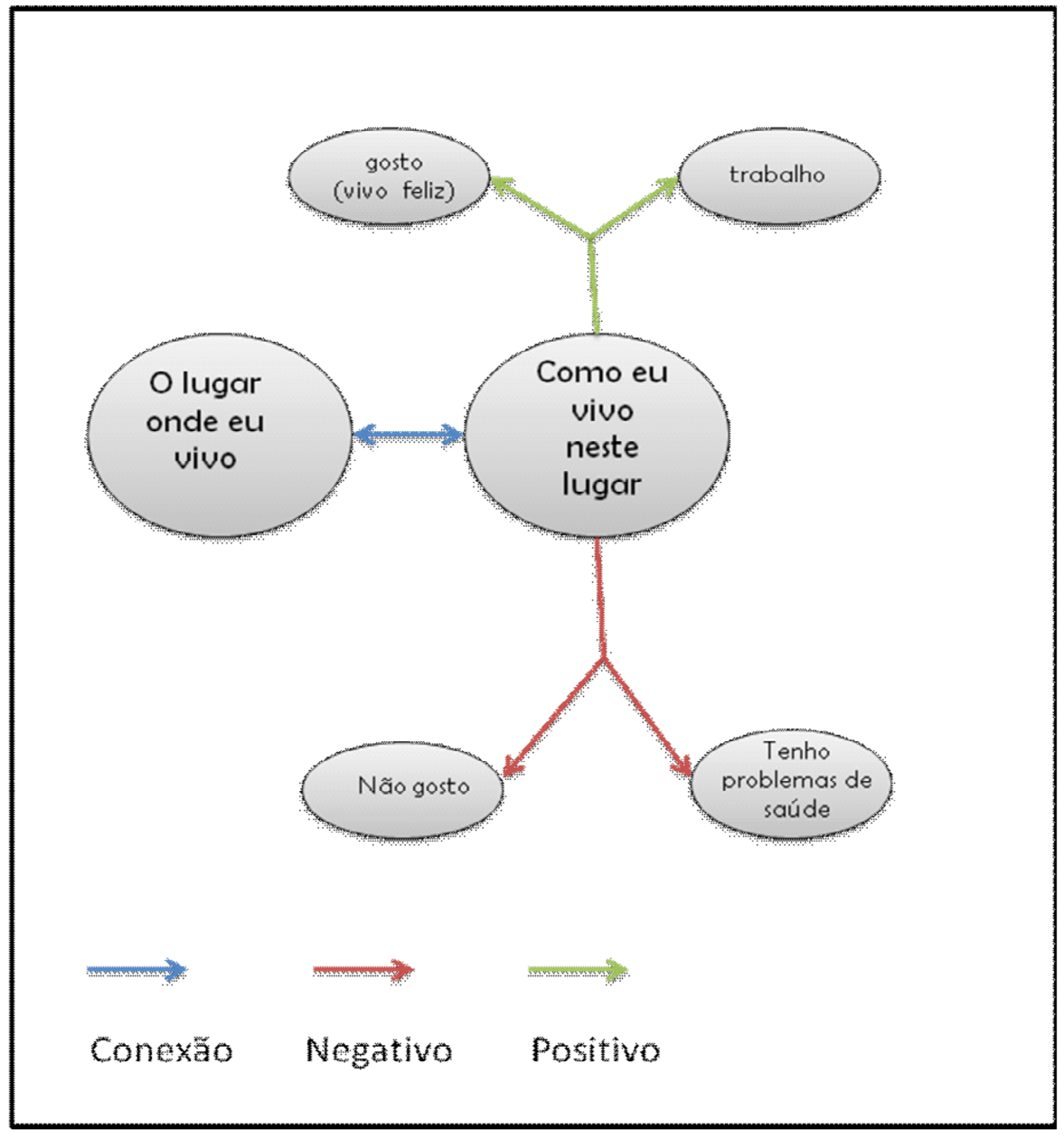

FIGURA 8 - MAPEAMENTO DAS ENTREVISTAS - 2

FONTE: PESQUISA DE CAMPO (2008).

ORGANIZAÇÃO: MOURA, N. (2008). 
Os problemas de saúde, sobretudo os respiratórios, foram apontados pelos moradores como uma agravante das condições ambientais do bairro. Tal fato se justifica por meio das considerações dos moradores acerca da poluição advindas das indústrias próximas ao bairro. Entretanto, as mesmas indústrias que trazem estes problemas para os moradores do bairro trazem também possibilidades de emprego e geração de renda aos moradores.

O que se pode inferir com as análises dos pontos centrais das entrevistas é que o cerne dos discursos, de uma maneira ou de outra, acabou girando em torno da questão da localização das indústrias, pois esta sempre foi citada pelos entrevistados - seja positiva, seja negativamente. A convivência com a zona industrial faz com que a prática social destas pessoas seja diretamente influenciada pelas atividades a ela inerentes. Os processos danosos e de desenvolvimento transitam no corpo de imagens ancoradas e objetivadas na vida cotidiana dos entrevistados. Desta maneira, se constituem em processos de representação social que transitam em um universo paradigmático, no qual a vida de relações se orienta por elementos contraditórios, mas que caminham lado a lado e fazem parte da mesma trama. Assim, o poder e a prática social norteiam a vida de relações, criando uma trama, um espaço onde se desenvolvem as atividades cotidianas, ou seja, um espaço de relações, que carrega em si elementos do real e da realidade e que está presente na cultura daqueles que dele fazem parte e nele convivem.

\section{ALGUMAS CONCLUSÕES POSSÍVEIS}

A sociedade contemporânea apresenta aos olhos um mundo repleto de contextos diferenciados nos quais interagem indivíduos das mais diferentes classes e culturas, que possuem diferentes tipos e modos de ver e compreender as situações cotidianas. Encontrar conceitos nestes contextos se constitui em tarefa instigante, para a qual as respostas são incertas e não se sabe ao certo onde se vai chegar ao iniciar o processo de análise.

A busca por conceitos passa pelo que já foi dito, pelo que se diz e, porque não, pelo que ainda se pode dizer sobre o fenômeno em estudo. A especificidade retratada neste trabalho (o espaço de relações planejamento urbano $x$ sociedade) passa pelo que pensam os dois universos de conhecimento (reificado e consensual) representados pelo poder e pela prática social que, embora distintos, interpenetram-se dando significado à relação entre o real e a realidade.

O espaço em estudo é apropriado de diferentes modos pelos universos que nele atuam. Para o reificado, ele se constitui no elemento chave em suas ações. Um espaço físico concreto, mas que ao mesmo tempo é também abstrato, ao passo que sua representação é obtida em imagens, traços sobre o papel ou pixels na tela do computador. Enquanto que para o universo consensual, este mesmo espaço físico é concreto, vivenciado e experimentado diariamente, nele se dão as relações inerentes à vida cotidiana de um grupo de pessoas, cujas representações são divididas e organizadas no mesmo patamar de conhecimento, aquele do senso comum, que reúne as ciências ou o que se sabe delas, em uma única ciência (MOSCOVICI, 2007). Sendo assim, pode-se dizer que o espaço do universo consensual vai além do físico concreto e observável, atua também no âmbito do simbólico e imaginário. A pesquisa de campo realizada mostrou um bairro com diferentes percepções a seu respeito, mas com elementos nucleares fundamentais que se repetem ou se contrapõem, dependendo do universo de conhecimento que a observa. Na tentativa de melhor elucidar os conceitos e contextos e evidenciar as respostas obtidas durante as análises das entrevistas, foi elaborada a figura 9.

A figura pode ser explicada da seguinte maneira: a proximidade entre as zonas gera o conflito de usos. Cada uso acarreta elementos interligados. Para cada elemento (ou contexto) se têm respostas dadas pelos atores, ou agentes. Tudo permeado pelas relações culturais estabelecidas para com o ambiente de vivência.

Relações estas que se estabeleceram no decorrer do processo de ocupação do bairro, permeadas pela compreensão, por parte do Poder Público Municipal, de que era interessante para as partes que a localização das residências fosse próxima a das indústrias. Os conceitos (conhecimento) para os dois universos emergem da Legislação que, articulando o real (o que deveria ser) e a realidade (aquilo que se mostra aos olhos) se constituem no espaço de relações planejamento urbano $x$ sociedade no bairro Capela Velha.

Neste espaço se encontram imbricadas as representações sociais ou teorias do senso comum, geradas pelas ações do Planejamento Urbano na vida cotidiana dos habitantes do bairro, que os ajudam a compreender sua própria realidade. Para Moscovici (2007) as pessoas possuem em suas teorias do senso comum elementos que ouviram falar, leram ou souberam de algum modo. Sendo desta maneira, as representações sociais inseridas no espaço de relações planejamento urbano $\mathrm{x}$ sociedade acabam por formar uma rede de 
relações ou, como salienta Moscovici (2007, p. 210) uma "rede de idéias, metáforas e imagens, mais ou menos interligadas livremente, e por isso, mais móveis e fluidas que teorias" científicas.

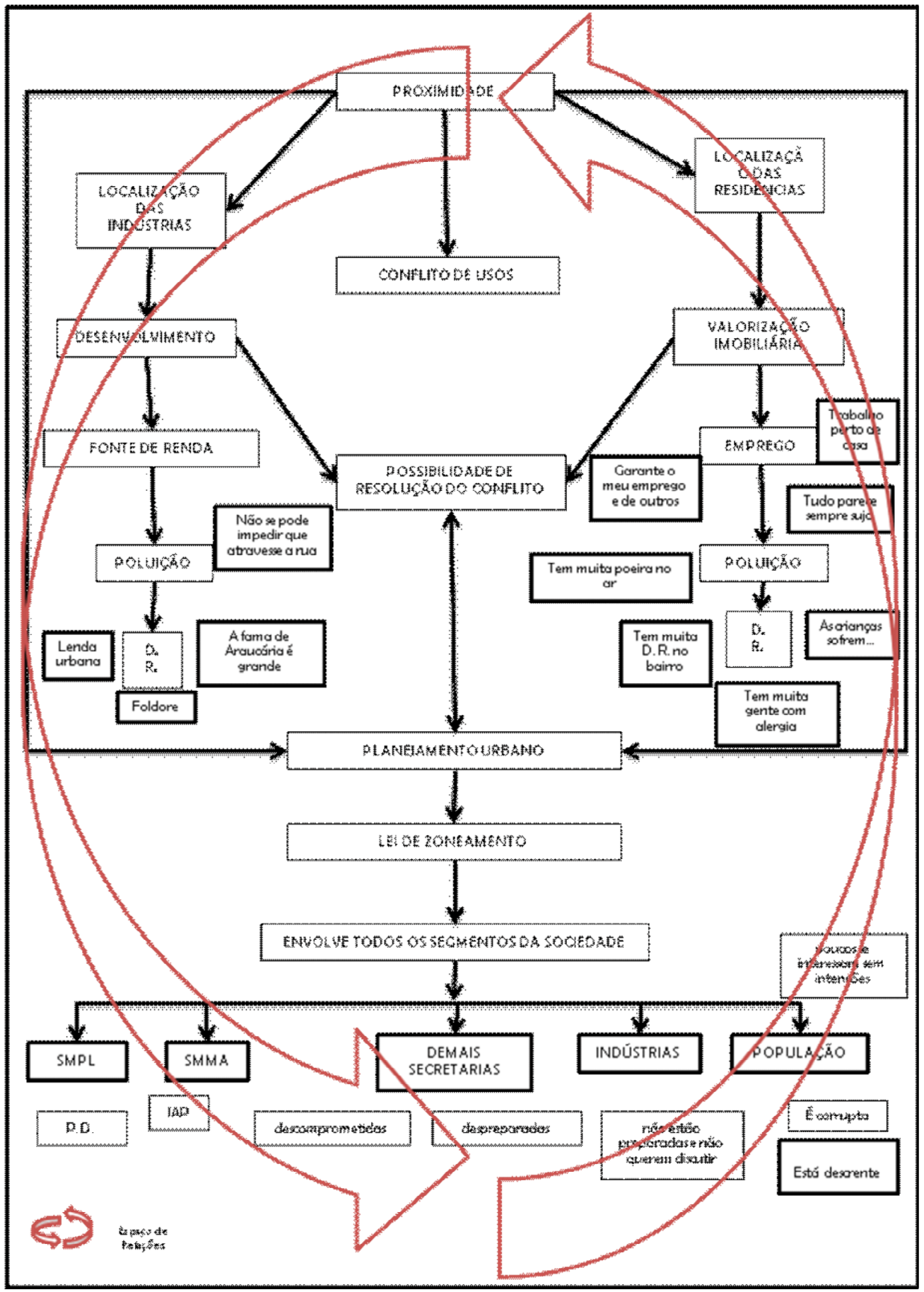

FIGURA 9 - CONCEITOS, CONTEXTOS E RESPOSTAS

FONTE: PESQUISA DE CAMPO (2008).

ORGANIZAÇÃO: MOURA, N. (2008). 
MOURA, N.; BAHL, M. Planejamento urbano e representações sociais....

A figura se apresenta, então, como um emaranhado de relações que se interconectam de algum modo. Nela se podem observar a atuação direta e indireta dos núcleos representativos que por sua vez, agregam ações, tanto da prática social quanto do poder. O cerne de todo encaminhamento que leva a compreensão deste espaço de relações se encontra no conceito de zoneamento urbano que se tinha no momento em que se organiza um centro industrial dentro do Município de Araucária, durante a década de 1970. Tal conceito levou à proximidade entre zonas com usos diferenciados e não equivalentes. Esta proximidade, por sua vez, transformou-se pouco a pouco na causa do conflito de usos dentro do Quadro Urbano Municipal.

Deste modo, tem-se a estrutura do espaço de relações planejamento urbano $x$ sociedade apoiada em elementos do universo reificado confrontados com os do universo consensual, agregando elementos transformados em conceitos que dão sustentação aos argumentos ou opiniões. A indústria, como primeiro pilar, próxima às residências possibilita desenvolvimento ao Município trazendo fonte de renda que garante a manutenção da vida particular e pública dos cidadãos. Entretanto, esta mesma proximidade remete também a elementos com conotação negativa, como a poluição, associada às doenças respiratórias pela população e negada como causa de tais males pelo setor público.

Como segundo pilar, tem-se as residências que estando próximas às indústrias têm suas edificações valorizadas. Fato que somado ao desenvolvimento trazido pelas indústrias, é apontado pelo Planejamento Urbano como uma possível solução ao conflito de usos, uma vez que a valorização motivaria os moradores a venderem seus imóveis e a área ficaria destinada ao setor de serviços, formando, em acordo com o novo Plano Diretor, um cinturão ao redor das zonas industriais, na intenção de filtrar os ruídos e a poluição advindos das indústrias para as zonas residenciais. A proximidade traz ainda para os moradores a possibilidade do emprego próximo ao lugar onde moram, proporcionando economia nos custos com transporte e mesmo com o tempo gasto com as locomoções diárias. Entretanto, a proximidade gera o sofrimento com os danos causados pela poluição: ruídos e fumaça são os principais agentes apontados pelos moradores como degradantes da qualidade ambiental do bairro. Neste contexto, surgem as doenças respiratórias mencionadas pelos moradores como consequências do ataque da poluição industrial.

No centro deste espaço, buscando garantir direitos e fazer cumprir a Lei, encontram-se as ações do Planejamento Urbano que busca por meio de sua Lei de Zoneamento, Uso e Ocupação do Solo envolver todos os segmentos da sociedade em um planejamento que tem por meta a resolução de seus problemas, entre eles o do conflito de usos. Entretanto, suas intenções encontram-se fora do imaginário dos outros segmentos da sociedade, dificultando as ações públicas. Seja pelo não comprometimento dos segmentos envolvidos, seja pelo descrédito no setor público, o envolvimento se mostrou, na maioria das vezes, descomprometido.

Então, pode-se dizer existente neste espaço de relações a oposição entre o reificado (real) e o consensual (realidade). Entretanto, tal oposição se configura, em dados momentos, como complementação. Neste contexto, as ações do poder penetram este espaço, atuando sobre e nele, gerando um campo onde os atores se posicionam e atuam em prol de interesses ora individuais, ora coletivos em torno das representações sociais que se configuraram como entendimentos acerca do conflito de usos. Neste sentido, a representação das ações do Planejamento Urbano no Município de Araucária, em especial no bairro Capela Velha, repercute intensamente no imaginário dos moradores, como uma situação em que seus direitos estão sendo constantemente feridos e que a solução para o conflito de usos está longe de ser alcançada. No entanto, estes mesmos moradores também não têm noção de que são agentes degradantes do meio em que vivem, pois suas construções, na maioria dos casos, encontram-se fora dos parâmetros estabelecidos pelo Planejamento Urbano Municipal. E, ainda, não aproveitaram a oportunidade de discutir os novos rumos que estão previstos no novo Plano Diretor Municipal, que, segundo os representantes do poder legal entrevistados, foi amplamente aberto às discussões com toda a comunidade em diversos momentos.

Os elementos simbólicos inseridos nesta estrutura demonstram as mais variadas essências, mas circundam o mesmo núcleo: a localização das indústrias no Quadro Urbano Municipal. Tais elementos simbólicos ou símbolos estruturados (BOURDIEU, 2003) são expressos nos discursos dos entrevistados como elementos chave que unem os pensamentos na prática social cotidiana em que se inserem. Assim, segundo entrevistados, o bairro é violento, poluído, barulhento, existem muitos casos de doenças respiratórias e a causa atribuída é sempre a mesma, a localização das indústrias. Mas, ao mesmo tempo, quando dizem que têm emprego próximo à residência, que o bairro é bem provido de equipamentos públicos, que a valorização imobiliária é crescente no bairro, a causa para tal é a mesma. No entanto, deixam escapar em trechos ou frases soltas, que a proximidade com as indústrias não é um fator positivo e que as benfeitorias que trazem não 
MOURA, N.; BAHL, M. Planejamento urbano e representações sociais...

superam os prejuízos.

As teorias criadas neste espaço de relações transitam no imaginário popular como obras raras a que todos têm acesso. Todos opinam a seu modo, sentem-se seguros em dar suas opiniões e convivem rotineiramente com o acesso às mesmas. Entretanto, tais obras não se encontram encerradas e a cada instante em que um novo elemento é considerado importante, um processo de familiarização, ancoragem e objetivação é realizado, incorporando o novo ao tradicional e todos passam a ter um novo contato e, de algum modo, dão sua "pincelada" na obra tornando-a parte de seu repertório.

\section{REFERÊNCIAS}

ARAUCÁRIA, Prefeitura do Município de. Da madeira ao aço - a industrialização de Araucária. Prefeitura de Araucária, 1999.

. Decreto $n^{\circ}$ 12.402/95. Araucária, 1995.

. Lei $n^{\circ} 584 / 81$. Lei de zoneamento, uso e ocupação

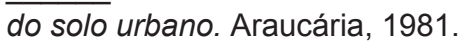

. Lei $n^{\circ}$ 1.454/03. Araucária, 2003a.

. Lei nº05/2006. Plano Diretor. Araucária, 2006.

BERGER, P. I.; LUCKMANN, T. A construção social da realidade. Tradução de Floriano de Souza Fernandes. 11 ed. Petrópolis: Vozes, 1985.

BOURDIEU, P. A economia das trocas lingüísticas. São Paulo: EDUSP, 1996.

. O poder simbólico. Tradução de Fernando Tomaz. 6 $\overline{\text { ed. Rio }}$ de Janeiro: Bertrand Brasil, 2003.

BRASIL, Constiuição (1988). Constituição: República
Federativa do Brasil. Brasília, DF: Senado Federal, 1988. 292 p. art. 30 e 182.

FIRKOWSKI. O. L. C. F. A nova territorialidade da indústria e o aglomerado metropolitano de Curitiba. Tese (Doutorado em Geografia) - USP, São Paulo, 2001.

GONÇALVES, C. W. P. Os (des)caminhos do meio ambiente. São Paulo: Contexto, 2002.

MOURA, N. Araucária / PR: planejamento urbano e representações sociais. Dissertação (Mestrado) - UFPR, Curitiba, 2009.

MOSCOVICI, S. As representações sociais. Investigações em Psicologia Social. Petrópolis: Vozes, 2007.

MOTA, S. Urbanização e meio ambiente. Rio de Janeiro: ABES, 1999.

. Representações sociais: o conceito e o estado atual da teoria. In: SPINK, M. J. O conhecimento no cotidiano. São Paulo: Brasiliense, 1993. 